\title{
Hayvancılığa Dayalı Yerel Sanayi İşletmelerinde Üretim ve Yerel Ekonomiye Katkı Sürecinde
} Yaşanan Sorunlar

\author{
İlkay UÇUM ${ }^{1}$ Bülent GÜLÇUBUK ${ }^{2}$ (D) \\ ${ }^{1}$ Tarımsal Ekonomi ve Politika Geliştirme Enstitüsü, ${ }^{2}$ Ankara Üniversitesi Ziraat Fakültesi Tarım Ekonomisi Bölümü \\ $\bowtie$ : i.ucum2017@gmail.com
}

\section{ÖZET}

Hayvancıllğın gelişmesinde ve yerel ekonomik kalkınmanın sağlanmasında hayvancılığa dayalı sanayi işletmeciliği büyük önem taşımaktadır. Hayvansal üretimin gelişmesi için, üretimin sanayi sektörüne entegre olarak gelişmesi gerekmektedir. Yerelde hayvansal üretime yönelik faaliyet gösteren işletmeler üretimin sürdürülebilirliği, katma değer yaratma, istihdam ve sosyal katkılar açısından temel işlevlere sahiptir. Ancak bu işletmeler, hayvancılığa dayalı ürünlerin önemli kısmının işlenmek amacıyla sanayiye aktarılamaması nedeniyle kapasitelerini tam olarak kullanamamakta ve bu durum işletmelerin yaratacağı yerel ekonomik katkıyı azaltmaktadır. Süreç içerisinde işletmelerin karşı karşıya olduğu sorunların başında, soğuk zincir sisteminin gelişmemiş olması, büyük ölçekli işletmeler karşısında üreticilerin örgütlenme eksikliği ve/veya işlevsizliği nedeniyle üretici aleyhine oluşan fiyat düzeyi ön sıralarda gelmektedir. Diğer yandan kırmızı et işleyen işletmelerin düşük fiyattan hayvan temin etme tutumu ve her zaman alım yapmaması da bir başka sorun olarak belirmektedir. Zira bu çalışma kapsamında alan çalışmasının yürütüldüğü Erzurum ilinde ele alınan işletmelerin bir çoğu istenilen miktarda süt temininde ve canlı hayvana erişim konusunda sıkıntı yaşadıklarını belirtmişlerdir. Bu bildiride konunun genel boyutları verildikten sonra, Türkiye'de en fazla hayvan sayısına sahip illerden olan Erzurum ilinde, hayvancılık faaliyetinde bulunan 80 yetiştirici ile ürün işleyen 20 mandıra ve 5 et işletmesi ile yapılan bir alan araştırmasının sonuçları verilmiş ve tartışılmıştır. Çalışmadan elde edilen ana bulgular ışığında; hayvancılıkta yaşanan sorunların çözümü için hem yetiştiriciliğin ve hem de işleme sanayinin karşılıklı hak ve çıkarlarını koruyan ve de yerel ekonomiye katkıyı artıracak bir entegrasyon zorunluluk arz etmektedir. Oluşturulacak entegrasyonun sürdürülebilirliğini sağlamada en önemli unsurlar ise; fiyat ve destek politikaları ile yerelde paydaşlar arasındaki etkileşim ve buna bağlı yerel strateji yaklaşımları olacaktır.

\author{
Makale Tarihçesi \\ Geliş : 20.10.2018 \\ Kabul : 27.12.2018
}

Anahtar Kelimeler
yerel ekonomik kalkınma,
kırsal kalkınma,
hayvancilık işletmeleri,
yerel entegrasyon

Araştırma Makalesi

Local Industrial Enterprises Based on Livestock Production and Problems in the Process of Contribution to the Local Economy

\section{ABSTRACT}

In the development of livestock and local economic development, animal husbandry-based industrial management is of paramount importance. For the development of animal production, production must be integrated into the industry sector. Firms operating in the field of animal production have basic functions in terms of production sustainability, value creation, employment and social contributions locally. However, these enterprises are not able to use their capacities fully due to the fact that most of the products based on animal husbandry cannot be transferred to the industry for processing and this situation reduces the local economic contribution created by the enterprises. In the process, the top level of the problems faced by the

\section{Article History}

Received : 20.10.2018

Accepted : 27.12.2018

\section{Keywords}

local economic development, rural development, livestock enterprises, local integration

\section{Research Article}


enterprises is the lack of organization of the cold chain system, the lack of organization of the producers in the face of large-scale enterprises and/or the inadequacy of the producers. On the other hand, the attitude of the firms that are processing red meat to buy animals at a low prices and the inconsistency in purchasing time duration appear as another problem. In the scope of this study, many of the enterprises discussed in the province of Erzurum where the field study was carried out stated that they experienced difficulties in supplying the milk in the desired quantity and access to the live animal. Looking general aspects of the this issue, Erzurum is the highest number of animals sustaining province in Turkey with 80 growers and 20 dairy farms in livestock functioning operations. The results of a field survey conducted by five family business in these areas were discussed in this study. In the light of the main findings obtained from this study; in order to solve the problems experienced in animal husbandry, an integration is necessary to protect the mutual rights and interests of both cultivation and processing industry and to increase the contribution to the local economy. The most important elements to ensure the sustainability of the integration will be price and support policies and local strategy approaches.

To cite: Uçum İ, Gülçubuk B 2018. Hayvancılı̆̆a Dayalı Yerel Sanayi İşletmelerinde Üretim ve Yerel Ekonomiye Katkı Sürecinde Yaşanan Sorunlar.KSÜ Tar Doğa Derg 21(Özel Sayı):44-54, DOI:10.18016/ksutarimdoga.v21i41625.472849

\section{GİRIş}

Hayvancılık, gıda temininde olduğu kadar bir gelir kaynağı olduğu için kırsal alanların kalkınması, kırsal kesimde hayat standartlarının yükseltilmesi, altyapı hizmetlerinin geliştirilmesi, dolayısıyla kırsal alandan kente göçün engellenmesi, devlet teşviklerinden faydalanması açısından da son derece önem arzeden bir sektördür. Hayvancılık sektörü tüketici yönünden ise artan nüfusun yeterli ve dengeli beslenmesinde önemli rol oynamaktadır. Hayvancılık ayrıca tarıma dayalı sanayi aracılığı ile milli gelir, ihracat ve istihdama katkı sağlamaktadır. TÜİK tarafindan yapılan "Tarımsal İşletme Yapı Araştırması 2006" verilerine göre, Türkiye'de tarımsal işletmelerin \%62.3'ünde hem bitkisel üretim hem de hayvansal üretim, \%37.2'sinde yalnızca bitkisel üretim, \%0.5'inde ise yalnızca hayvansal üretim yapılmaktadır (TÜİK, 2018). Araştırma alanını oluşturan Erzurum'da ise “2001 Genel Tarım Sayımı Tarımsal İşletmeler (hanehalkı) Anketi” sonucuna göre toplam 53.673 tarımsal işletmenin \%87.4'ünde hem bitkisel üretim hem de hayvan yetiştiriciliği, \%11'inde yalnız bitkisel üretim, \%1.6'sında ise yalnızca hayvan yetiştiriciliği yapılmaktadır.

Çizelge 1'de Türkiye ve araştırma alanını oluşturan Erzurum'da toplam sığır ve küçükbaş hayvan sayıları verilmiştir. Türkiye'de sı̆̆ır sayısı 2017 yılı itibariyle 15.9 milyon baş, toplam küçükbaş hayvan sayısı ise yaklaşık 44.3 milyon baştır. Erzurum'da toplam sığır sayısı 2017 yılı itibariyle 730 bin baş olup, Türkiye toplam sığır varlığının yaklaşık \%5’ini oluşturmuştur (Çizelge 1).

Tarıma dayalı sanayi, tarımsal ürünlerin farklı şekillerde işlenerek katma değerli ürünlerin oluşturulmasıdır. $\mathrm{Bu}$ anlamda tarımsal işleme, tarımsal ürünlerin taşınması, korunması ve ham maddeyi endüstriyel hammadde, gıda, yem gibi kullanılabilir hale dönüştüren bir dizi ekonomik faaliyetler olarak tanımlanabilir (Kachru, 2008).

Tarıma dayalı sanayilerin geliştirilmesi, kırsal alanlarda istihdam yaratılması kir-kent bağlantılarının ortaya çıkması ve kırsal alandan kentlere göçün önlenmesi için gereklidir. Ayrıca bu işletmeler bölgelerarası gelişme farklarının azalmasına yardımcı olduğundan politikalarla desteklenmektedirler. Ürünlere hem katma değer kazandırılması hem de yerel ekonomik kalkınmanın sağlanabilmesi açısından tarımsal ürün işleyen işletmeleri yerelde oluşturarak bu işletmelerin yerel ekonomilere katkılarının arttırılması önem taşımaktadır (Aluftekin, 2007).

Tarıma dayalı sanayilerin bir kolu olan hayvancılığa dayalı işletmeler ise üreticilerin ürettikleri süt ve canlı hayvana talep oluştururken, hayvansal ürünlerini işleyerek katma değer ve istihdam yaratmakta dolayısıyla yerel ekonomiye de katkıda bulunmaktadır. Yani hayvancılığa dayalı işletmeler üretimin yerinde değerlendirilmesini sağlamaktadır. Dolayısıyla üretimin ve üretici gelirinin devamlılı̆̆ını sağlamaktadır. 
Çizelge 1. Türkiye ve Erzurum'da hayvan sayısı (bin baş)

\begin{tabular}{|l|c|c|c|c|}
\hline \multirow{2}{*}{ Yıllar } & \multicolumn{2}{|c|}{ Türkiye } & \multicolumn{2}{c|}{ Erzurum } \\
\cline { 2 - 5 } & Sı̆̆ır & Toplam küçükbaş & Sığır & Toplam küçükbaş \\
\hline 2000 & 10761 & 35693 & 545 & 957 \\
\hline 2005 & 10526 & 31822 & 529 & 819 \\
\hline 2010 & 11370 & 29383 & 537 & 496 \\
\hline 2011 & 12386 & 32310 & 587 & 562 \\
\hline 2012 & 13915 & 35783 & 624 & 574 \\
\hline 2013 & 14415 & 38510 & 670 & 629 \\
\hline 2014 & 14223 & 41485 & 655 & 718 \\
\hline 2015 & 13994 & 41924 & 640 & 790 \\
\hline 2016 & 14080 & 41329 & 649 & 706 \\
\hline 2017 & 15944 & 44312 & 730 & 714 \\
\hline
\end{tabular}

Kaynak: TÜİK, 2018

Çalışma alanını oluşturan, Erzurum ili yaklaşık 1,4 milyon büyük ve küçükbaş hayvan varlığı ile Türkiye'de hayvan varlığı bakımından ilk sıralarda gelmektedir. Ayrıca Erzurum ilinin toplam arazi varlığının \%72.0'ının çayır ve meralar (\%63.0) oluşturduğundan hayvancllık bu ilde en önemli ekonomik faaliyetlerden birisidir (Anonim, 2014)

Literatürde konu ile ilgili çeşitli çalışmalar yapılmış olup bu çalışmalar daha çok hayvancıllğın yerel ekonomiye katkılarını içerirken hayvansal üretimin sanayiye aktarılmasında yaşanılan problemlere çok fazla değinilmemiştir.

Knox (2002), gelişmiş ülkelerin ekonomik gelişim süreçlerinde tarım sektöründe reformlar yaparak, tarımsal üretim ve verimliliği artırarak, tarım ve sanayi sektörlerini uyumlu hale getirerek sanayileşmeyi hızlandırdıklarını vurgulamıştır. Upton (2004), gelişmekte olan ülkelerin üçte birinde hayvansal ürünlerin tarımsal üretim katma değerinin yaklaşı yarısını oluşturduğunu belirtmektedir. Demirbaş ve Tosun (2005), Türkiye'de tarımın sanayi ile entegrasyonunda ortaya çıkan sorunları ele aldıkları çalışmada, tarım ve sanayi entegrasyonunun farklı şekillerinin olduğunu, dünyada ve Türkiye'de en yaygın entegrasyon şekillerinin kooperatifçilik ve sözleşmeli tarım formunda ortaya çıtığını belirtirken, diğer entegrasyon modellerin de yaygınlaştırılması gerektiği önerisinde bulunmuşlardır. Aluftekin (2007), doktora çalışmasında yerel düzeyde ekonomik kalkınmada tarımsal ürün işleyen KOBİlerin rolünü incelemiştir. Shejal (2013), tarıma dayalı sanayilerin üretici gelirine, tarım ve tarımsal istihdama, ürün çeşitlendirme ve kırsal alanların kalkınmasındaki etkilerini incelemeyi amaçlamıştır. Çalışmada tarıma dayalı sanayilerin tarımda çalışan iş̧̧ilerin ücretini, ürün çeşitliliğini ve istihdamı artırdığını, tarımsal sanayilerin kırsal nüfusa yeni iş alanları sağladığı belirtilmektedir.

Erzurum ilinde ağırlığını gıda ürünlerinin oluşturduğu bir ticari yapı görülmekte; süt ve süt ürünleri, et ve et ürünleri, un ve yem gibi tarımsal ürünler öncelikli yer tutmaktadır (Anonim, 2012). Erzurum'da hayvancılığın ilin ekonomik kalkınmasında büyük potansiyelinin olması, hayvancılığa dayalı işletmelerin durumunun analiz etme ihtiyacını doğurmaktadır. $\mathrm{Bu}$ noktadan hareketle çalışmanın amacı Erzurum'da hayvancılık faaliyeti gerçekleştiren üreticileri ve hayvancılığa dayalı işletmelerin mevcut durumunu analiz ederek; bu işletmelerin yerel ekonomiye yaptığı katkıların daha fazla olmasının önündeki engelleri tespit etmek ve öneriler geliştirmektir.

\section{MATERYAL ve METOT}

Araştırmanın ana materyalini, Erzurum ilinde KOBI kapsaminda faaliyet gösteren ve hayvansal ürün işleyen 20 süt işletmesi, 5 et işletmesi ile bu işletmelere girdi sağlayan ve hayvancılık faaliyetini gerçekleştiren 80 işletmeye uygulanan anketler sonrasinda elde dilen birincil veriler oluşturmaktadır. Araştırma kapsamına alınan süt ve et sektöründe faaliyet gösteren işletmelerin tespit edilmesinde Erzurum İl Gıda, Tarım ve Hayvancılık Müdürlüğü kayıtlarından faydalanmıştır.

Anket yapılacak üretici sayısının belirlenmesinde Gıda, Tarım ve Hayvancılık Bakanlığı TÜRKVET (Veteriner Bilgi Sistemi) verilerinden yararlanılmıştır. Ana çerçeveyi oluşturan işletmeler belirlendikten sonra bu işletmeler için büyükbaş hayvan sayllarma göre frekans tablosu düzenlenmiştir. Frekans tablosunda işletmelerin dağılımına göre, örnek hacminin belirlenmesinde Tabakalı Örnekleme yöntemi kullanılmıştır. Her tabakanın homojen olmasını sağlamak amacı ile işletmeler 1-7 baş, 8-14 baş ve $15+$ baş olmak üzere üç ayrı tabakaya ayrılmıştır.

Tabakalı Örnekleme Yöntemine göre örnek sayısı aşağıdaki formül kullanılarak hesaplanmıştır (Karagölge ve Peker 2002).

$$
\mathrm{n}=\frac{\left(\sum \mathrm{N}_{\mathrm{h}} \mathrm{S}_{\mathrm{h}}\right)^{2}}{\mathrm{~N}^{2} * \mathrm{D}^{2}+\sum \mathrm{N}_{\mathrm{h}} \mathrm{S}_{\mathrm{h}}^{2}}
$$


Örnek hacminin belirlenmesinde \%10 hata payı ile $\% 90$ güven sınırları içerisinde çalışılmıştır. Örnekleme sonucunda yapılacak anket sayısı 80 olarak tespit edilmiştir.

Tabakalara düşen anket sayısının belirlenmesinde Oransal Tabakalı Örnekleme yöntemi kullanılmıştır. $\mathrm{Bu}$ yöntemde, her tabakanın örnek büyüklüğü $\left(\mathrm{n}_{\mathrm{h}}\right)$, aşağıdaki formül kullanılarak hesaplanmıştır.

$n h=\frac{N h}{N} * n$

Analizlerin değerlendirilmesinde SPSS istatistiksel paket programı kullanılmıştır.

\section{BULGULAR ve TARTIŞMA}

\section{Üreticiler İle İlgili Bulgular}

Araştırma alanında görüşülen üreticilerin demografik özelliklerine bakıldığında; üreticilerin $\% 5.0$ 'inin 30 ve altı yaş grubunda, \%38.7'sinin 31-50 yaş grubunda yer aldığı görülmektedir. 51-65 arası yaş grubunda bulunan üretici oranı ise \%50.0'dir. Benzer sonuçlara yapılan bazı çalışmalarda rastlanılmaktadır. Demir (2009), Kars'ta süt sığırcılığı faaliyetini gerçekleştiren üreticilerin yaş ortalamasının 49.20 olduğunu tespit etmiştir. Aydın (2014), Trakya Bölgesi’nde işletme yöneticilerinin \%62.7'sinin 41-60 yaş aralığında, \%21.9'unun 20-40 yaş aralığında, \%5.4'ünün ise 61 yaş ve üzeri yaş grubunda olduğunu tespit etmiştir.

Tarımdan elde edilen gelirin özellikle küçük ölçekli işletmelerde faaliyet gösteren üreticiler için düşük olması, kırsal alanların cezbedici yönlerinin olmaması, sağllk, eğitim, eğlence gibi hizmetlerin kırsal alanlarda çok kısıtlı olması gibi nedenlerle gençler tarım dışı faaliyetlere yönelmektedir. $\mathrm{Bu}$ yüzden genç çiftçilerin yetiştirilmesi ve teşvik edilmesi, ekonomik olarak desteklenmesi, ayrica kırsal alanların yaşanabilir hale getirilmesi gerekmektedir. Tarımda ve kırsalda genç nüfusu tutmanın tek yolu kırsal kalkınma yani üreticilerin kalkınmasıdır. Çünkü kırsal nüfusun büyük çoğunluğu tarımla iştigal etmektedir.

Üreticilerin eğitim durumları incelendiğinde ise üreticilerin \%66.10'unun ilkokul mezunu, \%16.30'unun ortaokul mezunu, \%15.0'inin lise mezunu, \%1.30'unun ise okur-yazar olduğu belirlenmiştir. Üreticiler arasında okuma yazma bilmeyen olmamakla birlikte, üniversite düzeyinde eğitime sahip üretici oranı ise sadece \%1.30'dur. Aksoy (2008), Erzurum, Ağrı, Van ve Elazığ'daki üreticilerle yaptığı anket çalışmada, üreticilerin \%63.5'inin ilkokul ve \%11.3'ünün ise ortaokul mezunu olduğunu tespit etmiştir. Aydın (2014), yaptığı çalışmada üreticilerin büyük çoğunluğunun (\%82.8) ilkokul mezunu olduğunu belirlemiştir.

Tarımın daha dinamik bir yapıya kavuşması ve tarımın sanayiye entegre olması için üreticilerin hem teknik anlamda, hem de daha rasyonel düşünme anlamında eğitimli olmaları önem arzeden bir husustur. $\mathrm{Bu}$ nedenle eğitimli insanların tarıma kazandırılması ve mevcut üreticilerin faaliyetleri konusunda eksikliklerinin giderilmesi amacı ile ilgili kurumlar tarafından eğitim kursları ile desteklenmeleri önem arz etmektedir.

Üreticilerin hayvancılık faaliyetini gerçekleştirme amaçları, temel üretim çıtılarının sanayiye aktarılmasında ve bu temel çıtıları işleyen işletmelerin yerel ekonomiye katkılarının sağlanmasında önemli bir husustur.

Üreticilerin, hayvancılık faaliyetini gerçekleştirme amaçları Çizelge 2'de verilmiştir. Üreticilerin toplamı dikkate alındığında, işletmelerin \%70.0'inde hayvancılık faaliyeti geçimlik ve gelir sağlamak amacı ile yapılırken, yalnızca \%5.0'inde ticari amaçlı yapılmaktadır. İşletmelerin \%25.0'inde ise karma üretim yapılmaktadır. Daha fazla hayvana sahip üçüncü grup işletmelerin önemli bir kısmı ise (\%59.10) hem ticari hem de geçimlik amaciyla hayvancılık faaliyetini gerçekleştirmektedir.

Hayvancılık işletmelerinin üretim tipine göre dağılımı Çizelge 3'de gösterilmiştir. İşletmelerin \%58.70’i yalnızca süt sığırcılığı faaliyetini gerçekleştirirken, \%1,30’u yalnızca besi sığırcılığı, \%40.0'ı ise hem süt sığırcılığı hem de besi sığırcılığı faaliyetini gerçekleştirmektedir. Birinci gruptaki işletmelerin büyük bir kısmı (\%70.0) sadece süt sığırcılığ faaliyetini gerçekleştirirken, üçüncü gruptaki işletmelerin önemli bir kısmı (\%77.30) her iki üretim tipini de gerçekleştirmektedir.

Çizelge 2. Hayvancılığın yapılış amacına göre işletmelerin sınıflandırılması

\begin{tabular}{|l|c|c|c|c|c|c|c|c|}
\hline \multirow{2}{*}{$\begin{array}{l}\text { Hayvancılık faaliyetini } \\
\text { gerçekleştirme amacı }\end{array}$} & \multicolumn{2}{|c|}{ Grup 1 } & \multicolumn{2}{c|}{ Grup 2 } & \multicolumn{2}{c|}{ Grup 3 } & \multicolumn{2}{c|}{ Toplam } \\
\cline { 2 - 9 } & Sayı & $\%$ & Sayı & $\%$ & Sayı & $\%$ & Sayı & $\%$ \\
\hline $\begin{array}{l}\text { Geçimlik + gelir } \\
\text { sağlamak }\end{array}$ & 35 & 87.50 & 13 & 72.20 & 8 & 36.40 & 56 & 70.00 \\
\hline Ticari & 2 & 5.00 & 1 & 5.60 & 1 & 4.60 & 4 & 5.00 \\
\hline Karma (ticari+geçimlik) & 3 & 7.50 & 4 & 22.20 & 13 & 59.10 & 20 & 25.00 \\
\hline Toplam & 40 & 100.00 & 18 & 100.00 & 22 & 100.00 & 80 & 100.00 \\
\hline
\end{tabular}


Çizelge 3. Hayvancılık işletmelerinin üretim tipine göre dağılımı

\begin{tabular}{|l|c|c|c|c|c|c|c|c|}
\hline \multirow{2}{*}{ Üretim tipi } & \multicolumn{2}{|c|}{ Grup 1 } & \multicolumn{2}{c|}{ Grup 2 } & \multicolumn{2}{c|}{ Grup 3 } & \multicolumn{2}{c|}{ Toplam } \\
\cline { 2 - 9 } & Sayı & $\%$ & Sayl & $\%$ & Sayl & $\%$ & Sayı & $\%$ \\
\hline Süt sı̆̆ırcılı̆̆ & 28 & 70.00 & 15 & 83.30 & 4 & 18.20 & 47 & 58.70 \\
\hline Besi sığırcılığ & 0 & 0.00 & 0 & 0.00 & 1 & 4.50 & 1 & 1.30 \\
\hline Her ikisi & 12 & 30.00 & 3 & 16.70 & 17 & 77.30 & 32 & 40.00 \\
\hline Toplam & 40 & 100.00 & 18 & 100.00 & 22 & 100.00 & 80 & 100.00 \\
\hline
\end{tabular}

Demir (2009), Kars'ta süt sığırcılığı işletmeleri ile yaptığı doktora çalışmasında, araştırma kapsamına görüşülen 80 adet süt sığırcılık işletmesinde, işletme sahiplerinin \%82.5’inin sadece süt sığırcılığg ile geçimini sağladıklarını ve geri kalan işletme sahiplerinin ise süt sığırcılığı dışında ek iş olarak ticaret ile uğraştıklarını tespit etmiştir. Erzincan ili Çayırlı ilçesinde süt sığırcıları ile yapılan çalışmada, işletmecilerin \%51.6'sının sığırcıllğını ev ihtiyacını gidermek için yaptığı belirlenmiştir (Öztürk ve ark., 2014).

Görüşülen işletmelerde 33 üretici süt sığırcıllğı yanında besi üretimi de yapmaktadır. Besicilik yapan üreticilerin \%66.7'si besi faaliyetini kurban bayramında pazarlamak amacı ile yaparken, \%21.0'i ise kombinaya pazarlamak amacı ile yapmaktadır.
Erzurum'da kurban bayramları döneminde yoğun olarak görülen canlı hayvan sevkleri yetiştiricilerin en önemli gelir kaynağı durumundadır. Üreticiler kurban besisini tercih etmelerine, kombinenin devamlı alım yapmaması, kasaplar ve kombinenin düşük fiyattan alım yapmasının neden olduğunu belirtmektedirler. Üreticiler daha fazla maliyetten kaçınmak amacıyla canlı hayvan satışlarını çoğunlukla hayvanlar kesim yaşına ulaşmadan gerçekleştirdiğinden, bu durum ilde önemli bir katma değer kaybına da yol açmaktadır.

Araştırma kapsamında görüşülen işletmelerin \%68.80'i melez urkına sahip iken, yerli irka sahip işletme oranı \%22.50, kültür ırkına sahip işletme oranı yalnızca \%8.70'dir. (Çizelge 4).

Cizelge 4. İşletmelerin sahip oldukları büyükbaş hayvanların ırklara göre dağılımı

\begin{tabular}{|l|c|c|c|c|c|c|c|c|}
\hline \multirow{2}{*}{ Irklar } & \multicolumn{2}{|c|}{ Grup 1 } & \multicolumn{2}{|c|}{ Grup 2 } & \multicolumn{2}{c|}{ Grup 3 } & \multicolumn{2}{c|}{ Toplam } \\
\cline { 2 - 8 } & Sayı & $\%$ & Sayı & $\%$ & Sayl & $\%$ & Sayl & $\%$ \\
\hline Yerli & 9 & 22.50 & 7 & 38.90 & 2 & 9.10 & 18 & 22.50 \\
\hline Kültür & 3 & 7.50 & 1 & 5.60 & 3 & 13.60 & 7 & 8.70 \\
\hline Melez & 28 & 70.00 & 10 & 55.60 & 17 & 77.30 & 55 & 68.80 \\
\hline Toplam & 40 & 100.00 & 18 & 100.00 & 22 & 100.00 & 80 & 100.00 \\
\hline
\end{tabular}

Aksoy (2008), Erzurum'da yerli irk hayvan oranının $\% 60.7$ olduğunu, melez oranının $\% 31.20$ ve kültür ırkı oranının \% 8.10 olduğunu tespit etmiştir. Erzurum'da birkaç yıl öncesine kadar yerli hayvan ırkları çoğunluktayken, bu ırklardan elde edilen verim düşüklüğü nedeniyle ıslah çalışmaları yapılmış, bunu neticesinde melez ırkında önemli artışlar görülmüş̧ür. Aksoy'un yaptığı çalışma ile bu çalışma karşılaştırıldığına yerli ve melez ırklarındaki değişim açıkça görülmektedir.

Araştırma kapsamında görüşülen işletmelerin \%75.90'1 el ile sağım gerçekleştirirken, \%24.10'u makine ile süt sağımı gerçekleştirmektedir. Birinci gruptaki işletmelerin \%82.50'si el ile sağım gerçekleştirirken, ikinci grup işletmelerde bu oran \%72.20, üçüncü grup işletmelerde \%66.70'dir. Erzurum'da hayvancılık işletmelerinin büyük kısmında henüz ihtisaslaşma gerçekleşmediğinden süt sağımı el ile yapılmakta; bu durum hijyen ve verim açısından kayıplara yol açmaktadır.

Çizelge 5'de işletmeler tarafından üretilen sütün pazarlama kanalları yer almaktadır. İşletmelerin en önemli pazarlama kanalı mandıralar (\%77.20) oluşturmaktadır. Sütünü mandıra ve aracılar yoluyla pazarlayan üreticilerin büyük bölümü sütün bir kısmını da yine işletmelerinde kendileri işlemektedirler. İşletmelerin \%13.90'ı ise sütü yalnızca kendi işletmesinde değerlendirmekte yağ, peynir gibi süt ürünleri için işlemekte ve kendi imkânları ile pazarlamaktadır.

Uluslararası süt piyasaları (CLAL) verilerine göre 2017 yılında Türkiye'de üretilen toplam inek sütünün \%48.6'sı sanayiye aktarılmıştır. AB'de ise bu oran \%94'tür (Anonymous, 2018). Yavuz ve ark. (2016) tarafından, Erzurum'da ticarete konu olan süt miktarının, üretilen sütün yaklaşık \%10'u kadar olduğu ve bu oranın ülke geneli ile kıyaslandığında çok düşük olduğu bildirilmektedir.

Türkiye'de tarımsal ürünlerin daha çok aracı vasıtasıyla pazarlanması tüketicilerin de gidayı pahalı almasına neden olmaktadır. Bu problemin çözülmesinin yolu örgütlenmedir. Üreticiler kendi ürünlerini kendileri pazarlamada söz sahibi olmadıkları müddetçe ürünlerini değerinde pazarlayamayacaklar ve tüketicilerde gıdaya daha fazla para ödemeye devam edeceklerdir. 
Çizelge 5. Üretilen sütün pazarlama kanalları

\begin{tabular}{|l|c|c|c|c|c|c|c|c|}
\hline \multirow{2}{*}{$\begin{array}{l}\text { Süt pazarlama } \\
\text { kanalları }\end{array}$} & \multicolumn{2}{|c|}{ Grup1 } & \multicolumn{2}{c|}{ Grup2 } & \multicolumn{3}{c|}{ Grup3 } & \multicolumn{3}{c|}{ Toplam } \\
\cline { 2 - 9 } & Sayı & $\%$ & Sayı & $\%$ & Sayı & $\%$ & Sayı & $\%$ \\
\hline $\begin{array}{l}\text { Mandıra ve } \\
\text { kendisi }\end{array}$ & 32 & 80.00 & 15 & 83.30 & 14 & 66.70 & 61 & 77.20 \\
\hline Aracı ve kendisi & 3 & 7.50 & 0 & 0.00 & 4 & 19.00 & 7 & 8.90 \\
\hline $\begin{array}{l}\text { Yalnızca kendi } \\
\text { işliyor }\end{array}$ & 5 & 12.50 & 3 & 16.70 & 3 & 14.30 & 11 & 13.90 \\
\hline Toplam & 40 & 100.00 & 18 & 100.00 & 21 & 100.00 & 79 & 100.00 \\
\hline
\end{tabular}

Üreticiler, sütün üreticiden devlet eliyle ve düzenli alınmasını istediklerini, böyle olduğu durumda hayvancılığın daha çok gelişeceğinin altını çizmektedirler. En önemlisi de uzak köylerde yaşayan ve kendi pazarlama imkânı olmayan küçük üreticiler de değer zincirine katılabilme şansı elde edebileceklerdir.

Ayrıca, mandıra, alıcı vs. gibi farklı sistemlerle süt alımının olması fiyat dengesizliğine neden olmaktadır. Süt için, ödemelerin düzenli yapılması süt işletmelerinde işletmeciliği daha sürdürebilir kılmakta ve değer zincirinin birinci basamağını oluşturan işletme alt yapısının modernize edilmesine teşvik unsuru olabilmektedir.

Üreticiler besi hayvanlarını Erzurum'da kombina dışında nüfus yoğunluğunun fazla olduğu büyük illere kurban amaçlı göndermektedirler. Bunun dışında üreticiler besi hayvanlarını kendi çevrelerine, tüccar, cambaz, aracı vasitasiyla pazarlamaktadırlar. Erzurum Il Gida, Tarım ve Hayvancılık Müdürlüğü verilerine göre Erzurum'dan il dışına, yıllık olarak sevk edilen hayvan varlığının ortalama \%30.0'u kurban bayramı sürecinde yapılmaktadır. Kesimlerin ilde yapılmaması nedeniyle hayvanlar değerinde pazarlanamamaktadır.

Görüşülen üreticilerin tamamı ürünlerini değerinde satamadıklarını belirtmektedirler. Üreticilerin ürününü değerinde satamamasının nedenleri Çizelge 6'da verilmiştir. Üreticinin pazarladığı sütün satış fiyatının düşük olmasının en önemli nedeni $\% 42.70$ ile mandiralarm bir araya gelerek fiyat belirlemesidir. Üreticiler, özellikle mandıraların birleşerek süt fiyatını belirlemesinin büyük bir problem olduğunu belirtmektedir. Sektörde yeteri kadar rekabet olmadığından mandıralar üreticiden sütü istedikleri fiyata alabilmektedirler. Örgütsüzlük nedeniyle üreticiler mağdur edilirken,aracılar değer zinciri halkasının en çok kazananı olmaktadır. Ürettiği üründen para kazanmayan çiftçi ise, üretimini artırmak gibi bir çaba içerisine girmemektedir. Bu durum hayvansal ürün işleyen işletmelere daha az sütün aktarılmasına neden olmaktadır. Hayvansal ürün işleyen işletmelerin üretici lehine bir fiyat belirlemesi durumunda sanayiye aktarılan süt miktarının daha fazla olması sağlanabilir. Bu nedenle süt fiyatları konusunda üreticinin de söz sahibi olması aslında, hayvansal ürün işleyen işletmelerin düşük kapasite ile çalışmasına neden olan yetersiz süt arzı sorununu çözmesi noktasında önemlidir.

Kasapların ve kombinanın devamlı alım yapmaması ve düşük fiyattan alım yapması da besi faaliyetinde bulunan üreticilerin en önemli problemidir. Üreticiler, ESK ve diğer kesimhanelerin il hayvancılığının ihtiyacını karşılayacak kapasiteye sahip olmadığını belirtmektedirler. Üreticilerin ürünlerini değerinde satabilmeleri için getirdikleri öneriler Çizelge 7'de belirtilmiştir.

\section{Süt İşletmeleri İle İlgili Bulgular}

Araştırma kapsamında görüşülen süt işletmelerinin \%60.0'1 2-22 yll arasinda ve \%40.0' ise 23 yll ve daha fazla süredir faaliyet göstermektedir. İncelenen işletmelerin \%50.0'si 1-9 arasında personel istihdam ederken, yine \%50.0'si 10-49 arasında istihdam yaratmaktadır. Ayrıca işletmelerin istihdam ettiği personel sayısı sütün fazla olduğu aylarda artarken, kış aylarında biraz daha azalmaktadır.

Erzurum'da süt işleyen işletmelerde kalifiye eleman sıkıntısı bulunmaktadır. İlde sektörün ihtiyacına yönelik ve usta diye tabir edilen işi bilen personele ihtiyaç vardır. Bu hususta İl/İlçe Tarım ve Orman Bakanlığı Müdürlüğü ve üniversite ile işbirliği yaparak eğitimler vasıtasıyla bu eksikliği giderebilir. Nitekim bazı işletmeler diğer illerden peynir ustası getirdiğini bildirmişlerdir. Süt işletmelerinin hukuki yapıları incelendiğinde ise \%55.0'inin aile işletmesi olduğu, \%25.0'inin ise Anonim şirket olduğu belirlenmiştir. Görüşülen işletmelerin \%40.0'1 sütü soğutmalı tankerlerle alıp işletmeye getirdiğini belirtirken, \%55.0'i soğutucusu olmayan tankerlerle ve $\% 5.0$ 'i ise krom güğümlerle getirdiğini bildirmiştir. Sütü işletmeye getiren üretici ve toplayıcılarda soğutma sistemi kullanmamaktadır. Özellikle diğer illerden süt getiren işletmeler ve sütü kendi temin eden işletmeler soğutmalı sistem kullanmaktadırlar. Görüşülen işletmeciler, devletin yakın köylere süt toplama merkezi kurması gerektiğini veya belli bir sayıda süt ineğine sahip işletmelere süt tankı hibe edilmesi gerektiğini; soğutmalı süt tankı olmayanlardan sütün alınmaması gerektiğini ifade etmişlerdir. 
Çizelge 6. Üreticilerin ürününü değerinde satamamasının nedenleri*

\begin{tabular}{|l|c|c|c|c|c|c|c|c|}
\hline & \multicolumn{2}{|c|}{ Grup 1 } & \multicolumn{2}{|c|}{ Grup 2 } & \multicolumn{2}{c|}{ Grup 3 } & \multicolumn{2}{c|}{ Toplam } \\
\hline Ürünün değerinde satılmamasının nedenleri & Sayı & $\%$ & Sayı & $\%$ & Sayı & $\%$ & Sayı & $\%$ \\
\hline Üreticilerin sütü ucuza vermesi & 2 & 4,30 & 1 & 4,50 & 0 & 0,00 & 3 & 3,10 \\
\hline Mandıraların fiyat belirlemesi & $\mathbf{2 4}$ & $\mathbf{5 1 , 1 0}$ & $\mathbf{7}$ & $\mathbf{3 1 , 8 0}$ & $\mathbf{1 0}$ & $\mathbf{3 7 , 0 0}$ & $\mathbf{4 1}$ & $\mathbf{4 2 , 7 0}$ \\
\hline Üreticiler arasında birlik olmaması & 4 & 8,50 & 2 & 9,10 & 0 & 0,00 & 6 & 6,30 \\
\hline Rekabet yok & $\mathbf{7}$ & $\mathbf{1 4 , 8 0}$ & $\mathbf{4}$ & $\mathbf{1 8 , 2 0}$ & $\mathbf{8}$ & $\mathbf{2 9 , 6 0}$ & $\mathbf{1 9}$ & $\mathbf{1 9 , 7 0}$ \\
\hline $\begin{array}{l}\text { Kombinanın hayvanı ucuza alması ve her } \\
\text { zaman alım yapmaması }\end{array}$ & 4 & 8,50 & 1 & 4,60 & 4 & 14,80 & 9 & 9,40 \\
\hline Karkas et ucuza alınıyor & 2 & 4,30 & 0 & 0,00 & 3 & 11,20 & 5 & 5,20 \\
\hline İthal hayvan & 3 & 6,40 & 4 & 18,20 & 0 & 0,00 & 7 & 7,30 \\
\hline Belirli bir fiyat düzeyinin olmaması & 1 & 2,10 & 3 & 13,60 & 2 & 7,40 & 6 & 6,30 \\
\hline Toplam & 47 & 100,00 & 22 & 100,00 & 27 & 100,00 & 96 & 100,00 \\
\hline
\end{tabular}

*çoklu cevap kullanılmıştır

Çizelge 7. Üreticilerin ürünlerini değerinde satılabilmeleri için getirdikleri çözüm önerileri*

\begin{tabular}{|l|c|c|c|c|c|c|c|c|}
\hline \multirow{2}{*}{ Yapılabilecek Eylemler } & \multicolumn{2}{|c|}{ Grup 1 } & \multicolumn{2}{c|}{ Grup 2 } & \multicolumn{2}{c|}{ Grup 3 } & \multicolumn{2}{c|}{ Toplam } \\
\cline { 2 - 9 } & Sayı & $\%$ & Sayı & $\%$ & Sayı & $\%$ & Sayı & $\%$ \\
\hline Taban fiyatın belirlenmesi & 12 & 21.10 & 7 & 33.30 & 10 & 35.70 & $\mathbf{2 9}$ & $\mathbf{2 7 . 4 0}$ \\
\hline Üreticilerin birlik olması & 6 & 10.50 & 5 & 23.80 & 3 & 10.70 & 14 & 13.20 \\
\hline Kooperatifler & 13 & 22.80 & 3 & 14.30 & 5 & 17.90 & 21 & 19.80 \\
\hline Devletin süt fabrikası kurması & 9 & 15.80 & 3 & 14.30 & 4 & 14.30 & 16 & 15.10 \\
\hline Devlet destekleri & 10 & 17.50 & 1 & 4.80 & 3 & 10.70 & 14 & 13.20 \\
\hline Diğer & 7 & 12.30 & 2 & 9.50 & 3 & 10.70 & 12 & 11.30 \\
\hline Toplam & 57 & 100.00 & 21 & 100.00 & 28 & 100.00 & 106 & 100.00 \\
\hline
\end{tabular}

Erzurum'da üretilen sütün sanayiye aktarılması konusunda, soğuk zincirin geliştirilmesi, üreticilerin birleşmesi ve özellikle il ve ilçe merkezine uzak köylerde toplama merkezlerinin oluşturulması gibi sütün sanayiye aktarılmasında gerekli düzenlemeler yapılmalıdır. Böylece Erzurum bu konuda sahip olduğu potansiyeli kullanma imkânına sahip olabilecektir.

İşletmelerin günlük işledikleri süt miktarı, dönemler itibariyle önemli ölçüde değişiklik gösterdiği görülmektedir. Erzurum'da hayvanların meraya çıkmaya başladıkları ve en verimli oldukları NisanMayıs döneminde süt işletmelerinin günlük işledikleri süt miktarı ortalama 7.7 tondur. İşletmelerin, Ocak-Mart aylarında işledikleri süt miktarı ortalama 2.4 ton, Temmuz-Ağustos döneminde 4.7 ton, Eylül-Aralık döneminde 2.7 tondur. İşletmelerin yıl boyunca işledikleri süt miktarı ise ortalama 4.4 tondur.

Çizelge 8'de işletmelerin yıllık işledikleri süt miktarı verilmiştir. Görüşülen işletmelerin \%45’i yılda 100300 ton arasında süt işlerken, \%20'si 301-999 ve \%35’i 1000-1700 ton arasında süt işlemektedir. Bu sütün işlenmesinden civil peynir, beyaz peynir, kaşar peyniri, tulum peyniri, kolot peyniri, lor peyniri, yoğurt, ayran, kaymak ve tereyağı gibi çeşitli sanayi ürünleri elde edilmektedir.

İşletmelerin ortalama kapasite kullanım oranları ise \%52.00 olarak hesaplanmıştır. İşletmeciler ulusal firmalardan Pınar ve Ülker'inde ilden süt topladığını ve bu işletmelerle rekabet etme şanslarının olmadıklarını belirtmektedirler.

Çizelge 8. İşletmelerin yıllık işledikleri süt miktarı dağılımı

\begin{tabular}{|l|c|}
\hline İşlenen süt miktarı (ton) & $\%$ \\
\hline $100-300$ & 45.00 \\
\hline $301-999$ & 20.00 \\
\hline $1000-1700$ & 35.00 \\
\hline
\end{tabular}

Süt arzında mevsimlere göre yaşanan farklılık, üreticilerin kış aylarında süt gelirinden mahrum kalmalarına neden olurken, mandıra ve süt işleme tesislerinin her mevsim tam kapasite ile çalışmalarını engellemekte dolayısıyla işletme maliyetlerini artırmaktadır. $\mathrm{Bu}$ nedenle çĭ̆ süt üretiminin bütün yıla yayılmasını sağlayacak üretim planlaması, bölgedeki süt sektörünün gelişmesinde önemli bir faktör olarak görülmektedir.

İşletmelerin \%25'inin ylllı cirosu 0-50.000 TL aralığında, \%15’i 50.000-250.000 arasında, \%25’i 250.000-500.000 TL, \%10'u 500.000-1.000.000 ve $\% 25$ 'i $1.000 .000-5.000 .000$ TL arasinda ciroya sahiptirler.

İşletmelerin \%50'si süt ve süt ürünlerini doğrudan kendileri pazarlamaktadır. İşletmeler kendi yatırımları ile kurdukları parekende mağazalarında ürünlerini satmaktadır. Ayrıca bu işletmelerde de 
yine istihdam yaratılarak ekonomiye katkıda bulunulmaktadır. Yine işletmelerin \%15.4'ü ürünlerini doğrudan tüketici ve toptanciya pazarlamaktadır. Pazarlama kanalında toptancıların payı ise yaklaşık \%27, parekendecilerin payı ise yalnızca \%7.7'dir. Hem tüketici hem de toptancıya ürünlerini pazarlayan işletme oranı ise \%15.4'tür. Görüşülen işletmelerden 9'u ayrıca il dışına da ürün pazarladığını bildirmiştir. Bu iller Kars, Ardahan, Bayburt, İstanbul, Ankara, İzmir, Gümüşhane, Adana ve Bursa'dır. İşletmelerin \%80'i ürünlerini piyasaya kendi satış yerinde kendi markası ile \%5'i müşterilerinin istediği etiketle, \%15’i ise her iki şekilde de pazarladığını belirtmişlerdir.

Üretilen ürünün değerinde pazarlanabilmesi için, ürünün markalaşmasının sağlanmış olması çok önemlidir. İşletmelerin geleceklerini tehdit eden en önemli unsurlardan birisi büyük marketlerde yer bulan marka olmuş ürünlerdir. Bu ürünlerle rekabet etmenin yolu, birlikte hareket ederek ortak bir marka oluşturmaktır.

Görüşülen işletmelerin sektörde yaşadıkları problemler Çizelge 9'da gösterilmiştir. İşletmelerin yaşadıkları en önemli problem merdiven altı üretimdir. Merdivenaltı üretim, kayıtlı üretim yapan işletmelerin pazarlama alanlarını daraltarak piyasaya kalitesiz ürün girmesine ve haksız rekabete sebep olmaktadır. Bu hususta toplum ve tüketiciler yeterli bir şekilde bilinçlendirilmeli, haksız rekabet yapan firmalar engellenmelidir. İşletmelerin sektörde yaşadıkları diğer önemli problemler ise hammadde yani süte erişim, sütün kalitesi, finansman ve örgütlenme sorunudur.
Çizelge 9. Süt işletmelerinin yaşadıkları sorunlar

\begin{tabular}{|l|c|c|}
\hline İşletmelerinin yaşadıkları sorunlar & Sayı $^{*}$ & $\%$ \\
\hline Merdivenaltı üretim & $\mathbf{1 4}$ & $\mathbf{2 2 , 6}$ \\
\hline Hammaddeye erişim & 6 & 9,7 \\
\hline Finansman & 6 & 9,7 \\
\hline Sütün kalitesi & 6 & 9,7 \\
\hline Örgütlenme sorunu & 6 & 9,7 \\
\hline Fiyatların istikrarsızlığı & 5 & 8,1 \\
\hline Teknik eleman & 4 & 6,5 \\
\hline Düşük kapasiteli üretim & 4 & 6,5 \\
\hline Diğer & 11 & 17,5 \\
\hline Toplam & 62 & 100,0 \\
\hline
\end{tabular}

*çoklu cevap kullanılmıştır

Örgütsüzlük ve örgütlerin işe yaramamasından nedeniyle işletmeler birlikte hareket etmemektedir. Ortak menfaatlerin savunulması, sorunlara çözüm getirilmesi, planlı üretim ancak örgütlü bir yapıyla mümkün olacaktır. İzmir Ödemiş ilçesinde, süt sanayiinde faaliyet gösteren mandıraların ilçede üretilen sütün yaklaşık \% 40'ını işlemektedirler (Koyunbebe ve Konca 2006).

\section{Et İşletmeleri Hakkında Genel Bilgiler}

Görüşülen işletmelerden iki işletme mezbahane, kombina ve kesimhane olarak faaliyet gösterirken, bir işletme sadece besi ve karkas et üzerine faaliyet göstermekte, bir işletme kombina, diğer işletme ise et ürünleri imalatı üzerine faaliyet göstermektedir.

Çizelge 10'da kırmızı et ve et ürünleri üreten işletmelerin faaliyette bulundukları süreler ve işletme sahiplerinin yaşları yer almaktadır.

Çizelge 10. İşletmelere ilişkin temel bilgiler

\begin{tabular}{|l|c|c|c|c|}
\hline İşletme & İşletmenin konumu & Faaliyet süresi & $\begin{array}{c}\text { İşletme } \\
\text { sahibinin yaşı }\end{array}$ & $\begin{array}{c}\text { İşletme sahibinin eğitim } \\
\text { durumu }\end{array}$ \\
\hline 1 & Organize Sanayi Bölgesi & 32 & 45 & Lise \\
\hline 2 & Köy & 17 & 54 & Lise \\
\hline 3 & Organize Sanayi Bölgesi & 30 & 62 & İlkokul \\
\hline 4 & Organize Sanayi Bölgesi & 32 & 50 & Lise \\
\hline 5 & İlçe & 16 & 45 & Lise \\
\hline
\end{tabular}

Et işletmelerinden iki işletme Limited Şirket kuruluşu iken, iki işletme aile işletmesi ve diğeri de Anonim Şirket'tir. Ü̧̧ işletme 1-9 aralığında eleman çalıştırdığını belirtirken, bir işletme 10-49 ve bir işletme de 50-249 arasında eleman çalıştırdığını belirtmiş̧ir. Görüşülen et işletmelerinin \%37.50'si canlı hayvanı hayvan pazarından, \%25'i tüccardan temin ederken, \%12.50'si anlaşmalı olduğu üreticilerden temin etmektedir.

Görüşülen işletmeler sırasıyla günlük 10 ton, 1 ton, $300 \mathrm{~kg}$ ve bir işletme aylık 8-12 ton karkas et işlediğini belirtmiştir. Bir işletme de bu durumun değiştiğini ve bu konuda bilgi vermek istemediğini belirtmiştir. GTHB verilerine göre görüşülen 3 işletmenin yıllık et işleme kapasiteleri, 215, 407 ve 845 ton/yl'dır. Et işletmeleri kavurma, pastırma, sucuk, salam, fermente sucuk, isıl işlem görmüş sucuk, ısıl işlem görmüş sucuk benzeri ürün üretimi gerçekleştirmektedir. Görüşülen işletmelerden bir işletme 1.000.000-5.000.000 TL, iki işletme 500.0001.000.000 TL, bir işletme 50.000-250.000 TL aralığında ciroya sahip olduğunu bildirmiştir. Bir işletme ise cirosunu belirtmek istememiştir.

İşletmelerin işledikleri et ürünlerini pazarlama kanalları Cizelge 11'de verilmiştir. 
Çizelge 11. İşletmelerin ürünlerini pazarlama kanalları

\begin{tabular}{|l|c|c|}
\hline Pazarlama kanalları & Sayı $^{*}$ & $\%$ \\
\hline Direkt tüketiciye yönelik & 4 & 36.40 \\
\hline Toptancı & 2 & 18.20 \\
\hline Diğer illere pazarlama & 5 & 45.50 \\
\hline Toplam & 11 & 100.00 \\
\hline
\end{tabular}

*Çoklu cevap kullanılmıştır

Et işletmelerin \%36.40’ı doğrudan tüketiciye yönelik olarak kendi şarküterilerinde ürünlerini pazarlamaktadırlar. İşletmelerin tamamı Erzurum dışında diğer illere de ürün pazarlamaktadır. İşletmelerin Erzurum dışında ürünlerini pazarladıkları diğer iller; Rize, Trabzon, İstanbul, Ankara, Tokat, Ağrı, Van, Samsun'dur. İşletmeler ayrıca Doğu ve Güneydoğu Bölgesi'ndeki diğer illere de ürünlerini pazarladıklarını belirtmektedirler. Ayrıca bir işletme Migros ve Aytaç'a ürün verdiğini belirtmiştir.

İşletmelerin bu sektörde yaşadığınız en önemli sorunlar nelerdir sorusuna verdikleri cevaplar Çizelge 12'de yer almaktadır. Buna göre işletmelerin \%33.30'u pazara erişim konusunda sıkıntı yaşarken, \%26.70’i fiyatların istikrarsızlığı konusunda problem yaşamaktadır. İşletmeciler pazarlamaya ilişkin problemlerinin düşük fiyat, doğu-batı fiyat farkından ve personel yetersizliğinden ve haksız rekabetten kaynaklandığını belirtmişlerdir.

İşletmelerin markalaşma düzeyi yeterli seviyede olmadığından, dışa açılma şansları düşüktür. İlde doğal yollarla üretilen ve kalite açısından da oldukça iyi olan ürünlerin pazarlarda yer bulabilmesi ve kolay pazarlanması için belirli standartları karşılayan markaların oluşturulması gerekmektedir. Markalaşma kültürünün oluşturulması ve pazarlama yöntemlerinin geliştirilmesi alternatif pazar ağlarının geliştirilmesi hususunda avantaj sağlayacaktır. İşletmecilerin yaşadıkları diğer bir önemli problem ise fiyatların istikrarsızlığıdır. Fiyatlar özellikle sürekli değişen politikalara göre değişmektedir. Özellikle ithalatın yapıldığı dönemlerde fiyatların genel seyri değişmektedir.

Çizelge 12. İşletmelerin bu sektörde yaşadıkları temel sorunlar

\begin{tabular}{|l|c|c|}
\hline Sorunlar & Sayl* $^{*}$ & $\%$ \\
\hline Pazara erişim & 5 & 33.30 \\
\hline Fiyatların istikrarsılı̆̆ı̆ & 4 & 26.70 \\
\hline $\begin{array}{l}\text { Hammaddeye (canlı } \\
\text { hayvan) erişim }\end{array}$ & 3 & 20.00 \\
\hline Teknolojiye erişim & 2 & 13.30 \\
\hline Düsük Karkas ağırlığı & 1 & 6.70 \\
\hline Toplam & 15 & 100.00 \\
\hline
\end{tabular}

*Çoklu cevap kullanılmıştır
İşletmeler, iklim ve nakliye şartlarından dolayı, besicilik amacıyla gelen canlı dananın doğu bölgelerine ulaşmadığını ifade etmektedirler.

İşletmeler, problemlerine çözüm getirecek önlemleri şu şekilde ifade etmiştir.

* Hayvancılık faaliyeti konusunda bilinçli üretim yapılmasını sağlamak.

* U Üreticileri üretime teşvik etmek.

* Daha sonra üretilen ürünleri işlemek için Pazar imkanı sağlamak.

* Toplumu ve tüketicileri bilinçlendirmek.

- Haksız rekabet yapan firmaları tespit edip engel olmak.

* Üreticileri sadece kalitede rekabet ortamına çekmek.

* İşlenmiş et ürünleri üreten firmalara farklı destekler sunmak.

* İşletmelerde iyi analiz yapıp, gerek makine gerek işletme sermayesi konusunda problemlerin çözümüne samimi yaklaşmak ve desteklemek.

Görüşülen işletmelerden 2 işletme düşük kapasite ile çalışma gibi bir sorunları olmadığını; diğer 3 işletme ise özellikle talep yetersizliği nedeniyle düşük kapasite ile çalıştıklarını belirtmişlerdir. Düşük kapasite ile çalışan et işletmeleri kapasitelerinin kullanmak için sermayeye ihtiyaç duyduklarını, bu yüzden desteklerin özellikle sermayeye yönelik olması gerektiğini ve kredi faizlerinin düşürülmesi gerektiğini belirtmişlerdir.

\section{SONUÇ ve ÖNERILERR}

Tarıma dayalı sanayiler, özellikle kırsal alanlarda gerçekleştirilen üretime talep oluşturması, yeni yatırımların yapılmasında teşvik edici unsur olması, istihdam olanağı yaratması gibi birçok olumlu yönleriyle yerel ekonomik kalkınmanın sağlanmasında temel strateji haline gelmiştir. $\mathrm{Bu}$ yüzden bu tür işletmelerin yerel alanlarda oluşturulması ve gelişmelerinin sağlanması için gerekli politika önlemlerinin alınması önem arz etmektedir. Yerel alanda ekonomik yapıyı oluşturan potansiyel alanları tespit edip yatırımları ve devlet teşviklerini bu alanlara yönlendirmek kaynakların doğru ve akılcı kullanılması açısından da önemlidir. Erzurum'da hayvancılığa dayalı ürünleri işleyip katma değere dönüştüren işletmeler, Erzurum'un yerel ekonomik kalkınmasında stratejik öneme sahip olup, bölgenin diğer illerine göre daha fazla sayıdadır. Hayvansal ürün işleyen işletmelerin yerel ekonomiye ekonomik açıdan en önemli katkılarından birisi, kaynakları yerinde değerlendirmeleridir. $\mathrm{Bu}$ işletmeler üreticilerin temel hayvansal çıktılarını işleyerek çeşitli ürünlere dönüştürmekte ve tüketicinin hizmetine sunulmaktadır. Erzurum'da hayvancılığa dayalı faaliyet gösteren işletmelerin tamamı çiğ sütü, canlı hayvanı yerel üreticiden tedarik etmektedir. Süt işletmeleri yılda 100 ile 400 
ton arasında süt işleyerek, sütü katma değerli ürünlere dönüştürmektedir. Ancak Erzurum'da üretilen sütün az bir bölümü sanayiye ulaşmaktadır. Süt sektöründe soğuk zincirin yeterince gelişmemiş olması, uzak köylerden sütü getirmenin maliyetli olması ve bazı üreticilerin sütün üretici satış fiyatını düşük bulduğu için satmak yerine evde değerlendirmeyi tercih etmesi gibi nedenlerle sanayiye aktarılan süt düşük düzeyde kalmaktadır. $\mathrm{Bu}$ durum süt işletmelerinin düşük kapasite ile çalışmalarına neden olmaktadır. $\mathrm{Bu}$ hususta üreticiler, sütte bir taban fiyatın belirlenmesini ve devlet eliyle sütün toplanmasını istemektedirler. $\mathrm{Bu}$ önlemler alındığı taktirde çok daha fazla üretici değer zincirine katılmış olacak ve işletmelerin il ekonomisine yaptığı katkı artacaktır. Et işletmeleri günde $300 \mathrm{~kg}$ ile 10 ton arasında değişen kapasite ile üreticilerden temin ettikleri canlı hayvanı et ürünlerine dönüştürmektedirler. Özellikle et işletmeleri ürünlerini bölgedeki diğer illere de pazarlama olanağı bulmaktadırlar. Ancak et işletmeleri de süt işletmeleri gibi kapasitelerinin çok altında çalışmaktadır. Bunun nedeni üreticilerin fazla maliyetten kaçınıp hayvanları yeterli olgunluğa erişmeden özellikle kurban amacı ile il dışına sevk etmeleridir. Üreticiler, hayvanlarına yeterli talebin olmadığını belirtirken, işletmeler yeterli hayvan olmadığından şikayet etmektedir. $\mathrm{Bu}$ noktada üreticilerin, kombinenin, kasapların ve diğer paydaşların kırmızı et arzı ve talebi konusunda bir noktada buluşmaları ve sözleşmeli üretim yapılarak bir üretim planlaması yapılması önerilebilir. Canlı hayvanların ilde değerlendirilmesi durumunda katma değer kaybı engellenebilir ve bu işletmelerin yerel ekonomiye katkıları artabilir.

Erzurum'da hayvansal ürün işleyen işletmeler arasında birlikte çalışma kültürü ve ortaklık bilinci ve örgütlenme kültürü yeterli seviyede değildir. $\mathrm{Bu}$ işletmelerin önemli bir bölümü mikro veya küçük ölçekli ve aile şirketi olmalarından dolayı, tedarik, pazarlama, düşük kapasite kullanımı, rekabet gücü zayıflığı, finansman başta olmak üzere tek başlarına çözümünde zorlandıkları ortak sorunlara ortak çözümler üretmek için bir araya gelmeleri gerekmektedir.

Kalkınma Bankası tarafından yapılan üç yıldız kümelenme analizi çalışmalar neticesinde "Erzurum'da istihdam ve işyeri sayıları dikkate alındığında süt ve et ürünleri sektörlerinde potansiyel kümelenme olduğu sonucuna varılmıştır (Kafalı 2017). Bu noktada sektörde kümelenme konusunda atılacak ilk adım sektördeki paydaşları bir araya getirerek öncelikle örgütlenmenin, işbirliği yapmanın avantajları hususunda farkındalık yaratmaktır.

Küme kapsamında, üreticilerin üniversite-sanayi işbirliği ile üretim konusunda bilinçlendirilmesi, daha kaliteli, daha verimli daha hijyenik ve yıl boyunca sanayiye arz edilen üretim oluşturulmasını sağlayacaktır.

İşletmelerde kümelenme yaklaşımını hayata geçirilmesiyle, ortak girişimler, işbirliği ve anlaşmaların yaratacağı avantajlarla üretim ve pazarlama olanaklarını maksimize edilebileceği düşünülmektedir. Kümedeki aktörler, rekabet gücünü artırarak sektördeki büyük işletmelerin kendilerini pazar dışında bırakmalarına ancak bu şekilde engel olabilirler. Kümelenme vasitasıyla işletmelerin tek başlarına elde edemeyecekleri finansal sermaye, uzmanlaşmış bilgi, eğitim hizmetleri, araştırma ve geliştirme olanakları sağlanabilir. Ortak teknolojiler, ortak alım ya da dağıtım kanalları ve ortak işgücü havuzları ile maliyetler azalacak sektör bir ivme kazanacaktır. Kalifiye insan kaynağ $\breve{g}_{1}$ ve işbirliği ile geliştirilen rekabet gücü sayesinde hem Erzurum'un hem de bölgenin kalkınmasına katkıda bulunabileceği düşünülmektedir.

\section{TEŞEKKÜR}

Bu çalışma "Hayvancılığa Dayalı KOBİlerin Yerel Ekonomiye Katkıları: Erzurum İli Örneği” adlı doktora tezinden türetilmiştir.

\section{KAYNAKLAR}

Aluftekin N 2007. Yerel Düzeyde Ekonomik Kalkınmada Tarımsal Ürün İşleyen KOBI'lerin Rolü: Karaman İli Araştırması. Ankara Üniversitesi, Fen Bilimleri Enstitüsü Tarım Ekonomisi ABD, Doktora Tezi. $322 \mathrm{~s}$.

Aksoy A 2008. Doğu Anadolu Hayvancilığının Avrupa Birliğine Uyumu ve Rekabet Edebilirliğinin Analizi. Atatürk Üniversitesi, Fen Bilimleri Enstitüsü, Tarım Ekonomisi ABD, Doktora Tezi. $211 \mathrm{~s}$.

Anonim 2012. 81 İl Durum Raporu. Sanayi Genel Müdürlüğü.

Anonim 2014. Erzurum Tarım Strateji Belgesi (20142017). GTHB.

Anonim 2018. Tarımsal İşletme Yapı Araştırması, 2006. TÜİK.

Anonymous 2018. https://www.clal.it/en/europa. www.clal.it (Erişim Tarihi: 10.12.2018.

Aydın B 2014. Trakya Bölgesinde Faaliyet Gösteren Tarım İşletmelerinin Yapısal Özellikleri ve Etkinliklerinin Belirlenmesi. Namık Kemal Üniversitesi, Fen Bilimleri Enstitüsü, Tarım Ekonomisi Anabilim Dalı. Doktora Tezi, $150 \mathrm{~s}$.

Demir P 2009. Kars İli Süt Sanayi ve Mandıra İşletmelerinde Üretim ve Sanayi Entegrasyonunun Ekonomik ve Sosyo-Ekonomik Analizi. Ankara Üniversitesi Sağllk Bilimleri Enstitüsü, Hayvan Sağllğı Ekonomisi ve İşletmeciliği ABD, Doktora Tezi. 247 s. 
Demirbaş N, Tosun D 2005. Türkiye'de Tarımın Sanayi İle Entegrasyonu, Ortaya Çıkan Sorunlar ve Çözüm Önerileri. ADÜ Ziraat Fakültesi Dergisi $2(2): 27-34$.

Kachru RP 2008. Agro-processing industries in India: Growth, status and prospects, Indian Council of Agricultural Research, New Delhi. 1-7.

Kafalı 2017. Erzurum İli Uygun Yatırım Alanları Araştırması. Türkiye Kalkınma Bankası A.Ş. Teknoloji, Araştırma ve İş Geliştirme Daire Başkanlığı, Ankara.

Karagölge C, Peker K 2002. Tarım Ekonomisi Araştırmalarında Tabakalı Örnekleme Yönteminin Kullanılması, Atatürk Üniversitesi. Ziraat Fakültesi Dergisi 33 (3):313-316.

Koyubenbe N, Konca Y 2006. İzmir İli Ödemiş İlçesi Süt Sanayiindeki Gelişmeler Üzerine Bir Araştırma. Hayvansal Üretim 47(1): 47-53.
Knox Hugh W 2002. "Emerging Trends in Agricultural-Based Industries in the Northeast" Economic Trends. USA, Sebtember.

Öztürk S, Koçyiğit R, Tüzemen N 2014. Erzincan İlinde Süt Sığırcılığı Yapan İşletmelerin Yapısal Özellikleri:Çayırlı İlçesi Örneği. Tekirdağ Ziraat Fakültesi, 11(3):19-26

Shejal SS 2013. Agro-based Industries and Rural Development. ISSN 2277-8179.

Upton M 2004. The Role of Livestock in Economic Development and Poverty Reduction. PPLPI Working Paper No. 10, FAO.

Yavuz F, Sezgin A, Demir O 2016. Erzurum Sütçülük Sektöründe Soğuk Zincir İyi Uygulama Örneklerinin Oluşturulması ve Yayınlaştırılması Üzerine Bir Çalışma. TEAD, 2(1):42-50 